\section{'AC Harojoy' Apricot}

\author{
Richard E.C. Layne ${ }^{1}$ and David M. Hunter ${ }^{2}$ \\ Agriculture and Agri-Food Canada, Harrow, Ontario NOR 1G0, Canada
}

Additional index words. Prunus armeniaca, fruit breeding, cold hardiness, disease resistance

'AC Harojoy' apricot (Prunus armeniaca L.) is an early- to mid-season fresh market apricot released in 2000. The tree is cold hardy, disease resistant, and bears exceptionally attractive, good quality fruit suitable for the fresh market, commercial shipping, and home processing. 'AC Harojoy' was tested as HW446by members of the former Western Ontario Fruit Testing Association [WOFTA, now the Ontario Fruit Testing Association (OFTA)] in regional trials in southern Ontario, Canada, and it appears to be adapted to regions where 'Veecot' and 'Goldcot' can be successfully grown. This new cultivar, developed by Agriculture and Agri-Food Canada at Harrow, Ontario, Canada (AAFC-Harrow), is recommended by the Ontario Tender Fruit Producers' Marketing Board (OTFPMB) for trial planting in Ontario. 'AC Harojoy' has also been tested in the Rhône Valley, France, where it has performed well in comparison with other cultivars ripening in the same season. 'AC Harojoy', together with 'AC Haroblush' (Layne and Hunter, 2003a) and 'AC Harostar' (Layne and Hunter, 2003b), are the latest introductions from the AAFC apricot breeding program formerly located at Harrow.

\section{Origin}

'AC Harojoy' resulted from a controlled cross made in 1978 by R.E.C. Layne at AAFC- Harrow between 'Harlayne' (Layne, 1981) x 'Harcot' (Layne, 1978) (Fig. 1). Selected in 1984, 'AC Harojoy' was propagated on 'Haggith' apricot seedling rootstock (Layne and Harrison, 1975) beginning in 1985. 'AC Harojoy'/Haggith was placed in evaluation orchards at AAFC-Harrow beginning in 1986 and compared with 'Goldrich' and 'Veecot', which ripen in the same season. Trees were propagated in cooperation with WOFTA under the designation HW446 and placed in regional trials with WOFTAmembers beginning in 1987. 'AC Harojoy' is genetically stable and uniform.

Received for publication 2 Jan. 2002 Accepted for publication 19 May 2002. We thank H.O. Jackson, F.D. Stroud, E.W. Lamoure, M.D. St. Pierre, M.F. Gadsby, and D.B. Jessop for excellent technical assistance. We appreciate the assistance of the Western Ontario Fruit Testing Association and its growermembers in field performance evaluations.

${ }^{1}$ Retired.

${ }^{2}$ To whom reprint requests should be addressed. Present address: Univ. of Guelph, Dept. of Plant Agriculture, 4890 Victoria Ave. North, P.O. Box 7000, Vineland Station, Ontario LOR 2E0, Canada. E-mail: dhunter@uoguelph.ca

\section{Description}

Trees of 'AC Harojoy' are vigorous, semierect with medium to wide crotch angles. Young shoots have medium anthocyanin coloration on the tips. One-year-old shoots are of medium length and diameter, have very few laterals, and a few, small lenticels. Leaves are of medium size and medium green on the upper surface. The shape of the leaf base is attenuate, the leaf tip is acuminate, and the angle of the tip is broadly acute. Leaf margins are bicrenate, with little undulation, so leaves lie almost flat. Leaf petioles are long and thick with medium anthocyanin coloration on the upper side, and little anthocyanin coloration on the lower side. There are typically three large globose-shaped leaf glands on the petiole. In a sample of 30 leaves taken from the mid-point of 30 randomly collected shoots in mid-summer of 1995, leaf blades were $90.7 \pm 8.4 \mathrm{~mm}$ long and $74.2 \pm$ $6.4 \mathrm{~mm}$ wide, and leaf petioles were $37.3 \pm 3.3$ $\mathrm{mm}$ long and $1.9 \pm 0.2 \mathrm{~mm}$ thick.

Flower buds are borne on spurs and 1-yearold shoots. Flowers are large with white petals when fully open. The petals are circular in shape with a claw of medium length. The stigma is at the same level as the anthers.

Fruits of 'AC Harojoy' (Fig. 2) are large, oblong, trapezoidal in front view, and asymmetric along the suture, which is deep. The pedicel cavity is of medium depth and flaring, and the tip of the fruit is depressed with no stylar tissue present. On tree-ripe fruits, fuzz is inconspicuous and sparse, and the skin surface appears smooth to the naked eye. The ground
Fig. 1. Pedigree of 'AC Harojoy’ apricot. color of tree-ripe fruits is bright glossy orange, and a solid, bright red blush covers $\approx 40 \%$ of the fruit surface. In 1995, in a random sample of 30 firm ripe fruits, the fruit length was 54.4 $\pm 3.0 \mathrm{~mm}$, cheek width was $53.7 \pm 3.0 \mathrm{~mm}$, and thickness across the suture was $48.9 \pm 2.5$ $\mathrm{mm}$. Fruit weight was $75.5 \pm 11.4 \mathrm{~g}$, with stone weight accounting for only $4.6 \% \pm 0.6 \%$ of the fruit weight. The flesh is medium orange in color, firm to very firm, fine-textured, and moderately juicy. Fruit flavor is rated good, being well balanced between sweetness and acidity. Stones are small with an average fresh weight of $3.4 \pm 0.4 \mathrm{~g}$, tan in color when dry, oblong, plump, with a grainy surface, rudimentary wings and keel. The kernels are sweet like 'Harcot', not bitter like 'Goldrich' and 'Veecot'.

\section{Performance}

In a replicated orchard planted at AAFCHarrow, 'AC Harojoy' was compared with 'Harcot', 'Goldrich', and 'Veecot' from 1988 to 1995 (Table 1). 'AC Harojoy' and 'Veecot' ranked first for tree vigor. 'AC Harojoy' ranked first for winter hardiness and perennial canker (Leucostoma sp.) tolerance, and ranked first with 'Harcot' for resistance to bacterial leaf spot and bacterial fruit spot [both caused by Xanthanomas campestris pv. pruni (Smith) Dye]. Each of the four cultivars had the same productivity rating. Fruit ripening of 'AC Harojoy' was more uniform than 'Harcot', 'Goldrich', and 'Veecot'. Fruits of 'AC Harojoy'were equal in size to those of 'Harcot' and 'Goldrich', and larger than those of 'Veecot'. Of these four cultivars, 'AC Harojoy' was the most attractive and had the most red blush on the skin. Flesh firmness of 'AC Harojoy' was equal to 'Veecot' and greater than 'Harcot' and 'Goldrich'. Although fully freestone, 'AC Harojoy' was not as air free as 'Goldrich' and 'Veecot'. Fruit flavor of 'AC Harojoy' was commercially acceptable, although not as rich as 'Harcot'. For the rated characteristics, overall performance of 'AC Harojoy' was better than

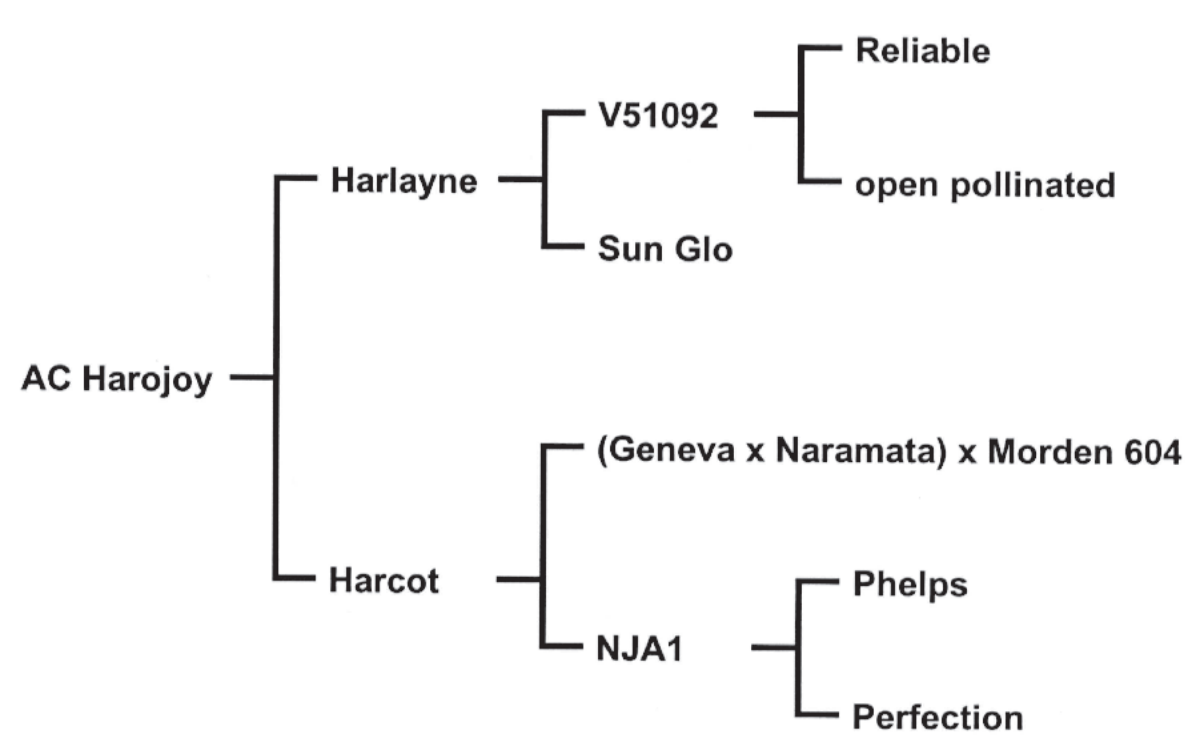


'Harcot', 'Veecot', and 'Goldrich'. Fruits of 'AC Harojoy' ripened with 'Goldrich', 3 d after 'Harcot' and $2 \mathrm{~d}$ before 'Veecot'. Thus, 'AC Harojoy' should be able to compete successfully with these three cultivars and has the potential to replace one or more of them in the future.

In 1990, ripened fruits were processed as canned halves in $40 \%(\mathrm{w} / \mathrm{v})$ syrup and as puree with $20 \%$ (w/w) granulated sugar. In masked identity taste panels, four trained panellists rated canned halves of 'AC Harojoy' as good to very good for color, flavor, texture, clarity of syrup, and integrity of pit cavity. By contrast, 'Veecot', the laboratory standard, had a good color rating but ratings for the remaining characteristics were only fair or fair to good. The overall rating for canned halves of 'AC Harojoy' was highest of the 10 cultivars and advanced selections tested. In evaluations of the processed puree, 'AC Harojoy' rated second of the same 10 cultivars and advanced selections and higher overall than 'Veecot', which was used as a reference standard. 'AC Harojoy' is, therefore, considered suitable for home processing as canned halves and as puree.

Controlled freezing tests carried out on dormant, fully acclimated shoots using a standard protocol (Layne and Gadsby, 1995) showed that flower buds and shoot xylem of 'AC Harojoy' were hardier than 'Veecot' (a medium hardy standard) but not quite as hardy as 'Goldcot' (a hardy standard). The 6-year (1989-94) average $\mathrm{T}_{50}$ for flower buds of 'AC Harojoy' was $-28.7^{\circ} \mathrm{C}$, while the average $\mathrm{T}_{50}$ for shoot xylem was $-35.3{ }^{\circ} \mathrm{C}$. The $\mathrm{T}_{50}$ for 'Goldcot' flower buds and shoot xylem was -29.4 and $-36.1{ }^{\circ} \mathrm{C}$, respectively. Layne and Gadsby (1995) reported that 'AC Harojoy' was more bud hardy than 'Goldcot' and 'Veecot' and was equally wood hardy as 'Goldcot'. Based on these results, 'AC Harojoy' should be adapted to the cooler areas in southern Ontario, Canada, and the neighboring U.S. states near the Great Lakes basin, where 'Veecot' and 'Goldcot' are successfully grown.

Based on tree performance, fruit quality, and winter hardiness evaluations, 'AC Harojoy', together with 'AC Haroblush' and 'AC Harostar' which are being introduced at the same time (Layne and Hunter, 2003a, 2003b), will provide growers with additional opportunities for supplying the mid-season apricot market.

\section{Availability}

In testing carried out at the Canadian Food Inspection Agency's Centre for Plant Health, Sidney, B.C.(CPH-Sidney), 'AC Harojoy'was found to be free of all known viruses, viruslike agents, viroids, and phytoplasmas, using an internationally approved range of woody and herbaceous host biological indicators, and by serological and molecular methods (D. Thompson, personal communication). Trees propagated from virus-free budwood have been planted in the Canadian Clonal Gene Bank at AAFC-Harrow. In annual monitoring at AAFC-Harrow, these budwood trees have been

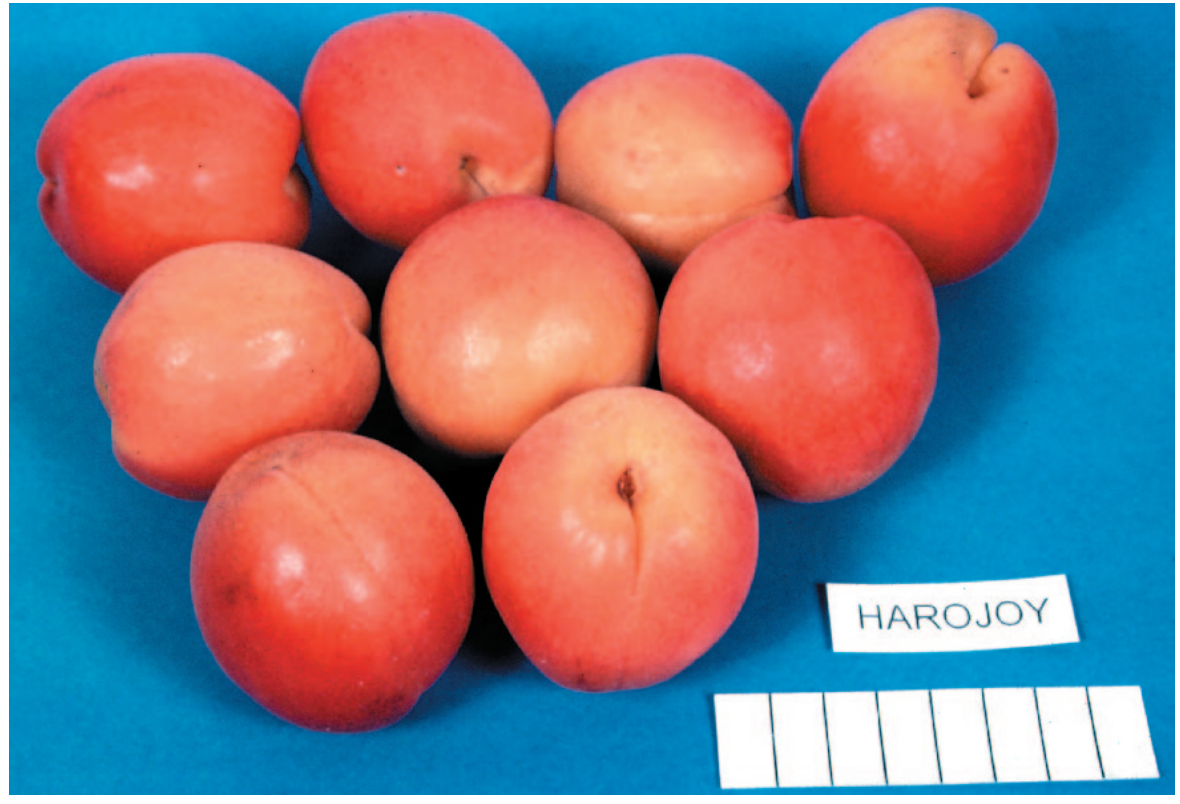

Fig. 2. Fruits of 'AC Harojoy' apricot (scale in centimeters).

Table 1. Long-term performance of 'AC Harojoy' at Harrow, Ontario, Canada, compared with 'Harcot', 'Goldrich', and 'Veecot' (1988-95). ${ }^{\text {' }}$

\begin{tabular}{lcccc}
\hline & \multicolumn{4}{c}{ Mean cultivar rating } \\
\cline { 2 - 5 } Characteristics evaluated & Harcot & Goldrich & AC Harojoy & Veecot \\
\hline Tree vigor & 6 & 7 & 8 & 8 \\
Winter hardiness & 8 & 6 & 10 & 7 \\
Perennial canker & 8 & 7 & 10 & 8 \\
Bacterial leaf spot & 9 & 8 & 9 & 9 \\
Bacterial fruit spot & 9 & 7 & 9 & 8 \\
Productivity & 5 & 5 & 5 & 5 \\
Ripening uniformity & 6 & 6 & 7 & 6 \\
Fruit size & 8 & 8 & 8 & 6 \\
Attractiveness & 7 & 7 & 8 & 7 \\
Blush & 3 & 1 & 4 & 1 \\
Flesh firmness & 7 & 7 & 8 & 8 \\
Flesh adherence to pit & 7 & 10 & 9 & 10 \\
Flavor & 7 & 6 & 6 & 6 \\
Total score & 90 & 85 & 101 & 89 \\
Mean ripe date & 16 July & 19 July & 19 July & 21 July \\
TRings & & &
\end{tabular}

${ }^{2}$ Ratings were subjective on a scale of 1 (least desirable) to 10 (most desirable). Except for blush, ratings of 1 to 4 are considered unacceptable for a commercial cultivar; ratings of 5 and 6 are commercially acceptable; while ratings $\geq 7$ indicate a good to excellent level of performance.

${ }^{y}$ Means for three single-tree replicates planted in a completely random design.

tested free of prunus necrotic ringspot virus, prune dwarf virus, and tomato ringspot virus using herbaceous (cucumber) and woody ('Shirofugen' cherry) indicators. Limited quantities of virus-tested budwood are available from AAFC-Harrow and CPH-Sidney. Testing of 'AC Harojoy' is subject to signing a non-propagation testing agreement with AAFC-Harrow. Information on commercialization licenses in Canada and the United States can be obtained by contacting the Director, Agriculture and Agri-Food Canada, Greenhouse and Processing Crops Research Centre, Harrow, Ontario NOR 1G0, Canada. 'AC Harojoy' has been protected in the European Union on behalf of Agriculture and Agri-Food Canada by Star Fruits, Route d'Orange, 84860 Caderousse, France, to whom inquiries for commercial propagation of 'AC Harojoy' in the European Union should be directed.

\section{Literature Cited}

Layne, R.E.C. 1978. 'Harcot' apricot. HortScience 13:64-65.

Layne, R.E.C. 1981. 'Harlayne’apricot. HortScience 16:97-98.

Layne, R.E.C. and M.F. Gadsby. 1995. Determination of cold hardiness and estimation of potential breeding value of apricot germplasm. Fruit Var. J. 49:242-248.

Layne, R.E.C. and T.B. Harrison. 1975. 'Haggith' apricot: Rootstock seed source. HortScience $10: 428$

Layne, R.E.C. and D.M. Hunter. 2003a. 'AC Haroblush' apricot. HortScience 38:142-143.

Layne, R.E.C. and D.M. Hunter. 2003b. 'AC Harostar' apricot. HortScience 38:140-141. 